Шпік Н. Р., к.е.н., доцент Львівський національний аграрний університет м. Дубляни, Львівська область, Україна

DOI: https://doi.org/10.30525/978-9934-26-028-5-42

\title{
ДІДЖИТАЛІЗАЦІЯ ЯК ІНСТРУМЕНТ ЕКОНОМІЧНОГО ЗРОСТАННЯ
}

Економічне зростання, підвищення конкурентоспроможності національної економіки та якості життя громадян в Україні неможливе без широкої та повсюдної діджиталізації (використання цифрових - інформаційнокомунікаційних технологій (IКТ)) суспільного виробництва, оскільки іiі позитивні зовнішні ефекти кумулятивно впливають на соціальний, економічний, 
технологічний, інтелектуальний, інфраструктурний потенціал за рахунок самопідтримуючого синергетичного ефекту. 3 огляду на це ІКТ сьогодні вважаються важливим фактором пришвидшення розвитку провідних країн світу та зростання їх конкурентоспроможності.

Прогресивний вплив IКТ на розвиток соціально-економічних систем загальновизнаний. Земельна реформа в Україні триває вже не один рік, тож метою діджиталізації буде прискорення цього процесу, та наповнення кадастру геоінформаційними даними.

Діджиталізація - буквально «оцифровування» - у широкому сенсі означає перехід інформаційного поля на цифрові технології. Світовим трендом наразі є «Індустрія 4.0»- це фаза цифровізації економіки, де головну роль відіграють аналітика великих даних («BigData») та сучасні космічні технології. Частка цифрової економіки у ВВП передових країн до 2030 року сягне 50-60\%.

Варто відмітити п'ять основних трендів із залучення сучасних IT-технологій:

1. Розвиток систем точного землеробства 3 використанням технологій глобальних навігаційних супутникових систем i систем дистанційного зондування Землі.

2. Безпілотні технології.

3. Системи віддаленого обліку i контролю матеріальнотехнічних цінностей.

4. Інтелектуальний аналіз даних і сценарне моделювання.

5. Агроскаутінг, який передбачає використанням мобільних додатків для моніторингу стану землекористування у межах конкретного поля.

В Україні закладено фундамент Національної інфраструктури геопросторових даних, вперше з'явиться цифрова топографічна база даних. Створюватимуть іiі за допомогою аерофотозйомки. 3D-моделі місцевості надаватимуть інформацію про земельні ресурси, лісові масиви, забудову, рослинність, лінії електромереж тощо. 
Розвитку космічних технології для моніторингу ефективності землекористування сприяють міжнародні програми, які діють в Україні. Так, Світовий банк за фінансової підтримки СС запустив в Україні пілотний проект супутникового моніторингу використання сільськогосподарських земель. Проект у рамках 5-річної програми 3 підвищення прозорості та ефективності управління земельними активами в Україні «Supporting Transparent Land Governance in Ukraine» на даний момент реалізовано в трьох областях: Львівській, Київській та Миколаївській. Його впроваджує компанія EOS.

Також Міністерством розвитку економіки, торгівлі та сільського господарства України презентовано проект «Відкрита земля». Головна мета - забезпечити прозорість та відстежуваність земельних відносин, а також надати інформацію про власників землі, вартість угод купівлі-продажу та оренди, концентрацію земель в одних руках тощо.

Основним інструментом названого проекту є геопортал, де зібрані результати обробки даних дистанційного зондування земель України та підключена публічна кадастрова карта. На отриманій карті геопорталу можна побачити: межі ділянок, чи обробляються вони чи ні, які культури там ростуть, зволоженість грунту, який індекс вегетації культур на момент зйомки тощо. За допомогою даних 3 геопорталу вирішуються питання незареєстрованих земель, які використовуються, але 3 яких не платяться податки [4].

Відповідно до Закону України «Про державний земельний кадастр» ДЗК - це єдина державна геоінформаційна система відомостей про землі, розташовані в межах державного кордону України, цільове призначення, обмеження у використанні, а також дані про кількісну і якісну характеристику земель, їх оцінку, про розподіл земель між власниками і користувачами.

Ведення Державного земельного кадастру здійснюється шляхом створення відповідної державної геодезичної та картографічної основи, внесення відомостей та змін про об’єкти 
Державного земельного кадастру, їх оброблення та систематизації [1].

В Україні на даний час діють більше дванадцяти галузевих та відомчих кадастрів, в яких відображена картографічна інформація. Крім того, існують окремі геоінформаційні системи, що створюються органами державної влади та органами місцевого самоврядування.

Найбільші проблеми на сьогоднішній день - це дублювання роботи на центральному, регіональному та місцевому рівнях та обмеженість доступу до державної інформації. Платформа дасть змогу дозволити вносити свої дані для всіх рівнів, і таким чином ми позбудемось дублювання інформації. За підрахунками це дозволить зекономити приблизно 100 млн грн на рік.

Основна ціль пропонованої реформи Держгеокадастру оновлення підоснови ДЗК. Мова йде про створення ортофотопланів та 3-D моделі місцевості території України.

Наступним кроком має бути наповнення відомостями ДЗК. Це, зокрема, передбачає:

- стовідсоткову інвентаризацію державних сільськогосподарських земель;

- інвентаризацію решти державних земель;

- внесення відомостей про якісні характеристики земель [2].

Повна інвентаризація державних сільськогосподарських земель йде до завершення і має на меті:

- відкриття даних про координати поворотних точок меж земельних ділянок;

- розширення доступу до режиму читання для професійної спільноти;

- повна інтеграція із державними галузевими кадастрами i реєстрами;

- проведення пілотного проекту 3 надання інженерамземлевпорядникам можливостей внесення відомостей до Державного земельного кадастру;

- запровадження безкоштовного сервісу перевірки обмінного файлу під час виконання землевпорядних робіт; 
- перенесення відомостей про земельні ділянки, права на які виникли та невнесені у ДЗК.

Наступним кроком реформи, заплановано діджиталізацію землеустрою, де передбачено:

- уніфікація вимог до документації із землеустрою;

- складання документації із землеустрою виключно в електронній формі;

- діджиталізація роботи державного фонду документації із землеустрою;

- запровадження публічності розроблених проектів землеустрою за кожним суб'єктом (у ДЗК, реєстрі інженерівземлевпорядників, фонді документації із землеустрою);

- скасування дозволів на розробку документації із землеустрою та експертизи землевпорядної документації;

- зменшення кількості погоджувальних процедур до однієї [3].

Інформація геокадастру не була раніше закрита, але вона була неузгоджена. Тоді як система НІГД об'єднує геопросторові дані як державного, так і приватного та місцевих секторів. Це буде єдине вікно входу, інструментарій аналізу інвестиційної привабливості та управління тим чи іншим об'єктом. Головна задача - поєднати всі дані на одній основі.

На жаль, ми останні в Європі, хто це запроваджує. Однак плануємо, що буде відкритий доступ до всієї базової інформації. Таких шарів у нас планується 17. Щоб дізнатись, хто володіє земельною ділянкою, потрібно буде авторизуватись електронним ключем [5].

Варто зауважити, що нормативне забезпечення у регулюванні даного питання потребує невідкладного вдосконалення. Уряд визначає, що документація із землеустрою починаючи 3 2019 року повинна бути в електронній формі. Планується відкриття координат поворотних точок земельних ділянок. Крім того, в процесі реформи передбачається скасування реєстрації апаратури супутникових радіонавігаційних систем.

Земельні відносини повинні бути доступними. Станом на сьогодні вже відкриті наступні відомості: 
- рішення щодо розпорядження землями сільськогосподарського призначення державної власності;

- висновки експертизи землевпорядної документації;

- висновки про розгляд проектів землеустрою щодо відведення земельних ділянок;

- заходи державного контролю за використанням та охороною земель та їх результати.

На черзі - оприлюднення інформації про дозволи на зняття та перенесення поверхневого (родючого) шару грунту.

«Фактично, новий Держгеокадастр - це карта, на яку будуть нанесені всі необхідні об'єкти: природно-заповідний фонд, ліси, природні об'єкти, окремі земельні ділянки, надра. Ця інформація нині є предметом маніпуляції з боку іiі розпорядників. Зараз для отримання відповідних інформаційний довідок необхідно звертатись в безліч інстанцій. Основна задача - об єднати всі кадастри і бази даних. Це захистить громадян від корупції та створить передумови для інвестування. Інвестор зможе якісніше розраховувати свої ризики та бачити, куди вигідніше інвестувати».

\section{Література:}

1. Діджиталізація у сфері земельних відносин. URL: https://agropolit.com/ blog/350-didjitalizatsiya-u-sferi-zemelnih-vidnosin.

2. Діджиталізація Держгеокадастру: чи стане система доступна кожному URL: http://chp.com.ua/all-news/item/64212-didzhitalizatsiya-derzhgeokadastru-chistane-sistema-dostupna-kozhnomu.

3. Держгеокадастр 2020: чого очікувати? URL: http://agrobusiness.com.ua/agro/ekspertna-dumka/item/16427-derzhheokadastr-2020-choho-ochikuvaty.html.

4. Земельний кодекс України. URL: https://zakon.rada.gov.ua/laws/show/ 2768-14.

5. Назріла і перезріла земельна реформа: як і навіщо працює відкритий геокадастр URL: http://www.nrcu.gov.ua/news.html?newsID=93189. 